Full length article

\title{
Increasing the potential of cell-penetrating peptides for cancer therapy using a new pentagonal scaffold
}

\author{
Diana Duarte $^{\mathrm{a}, \mathrm{b}, \mathrm{c}}$, Alexandra G. Fraga ${ }^{\mathrm{d}, \mathrm{e}}$, Jorge Pedrosa ${ }^{\mathrm{d}, \mathrm{e}}$, Fátima Martel ${ }^{\mathrm{c}, \mathrm{f}}$, Nuno Vale ,a,b,c,g,* $^{\text {, }}$ \\ ${ }^{a}$ Laboratory of Pharmacology, Department of Drug Sciences, Faculty of Pharmacy, University of Porto, Rua de Jorge Viterbo Ferreira, 228, 4050-313, Porto, Portugal \\ ${ }^{\mathrm{b}}$ Institute of Molecular Pathology and Immunology of the University of Porto (IPATIMUP), Rua Júlio Amaral de Carvalho, 45, 4200-i35, Porto, Portugal \\ ${ }^{\mathrm{c}}$ Instituto de Investigação e Inovação Em Saúde (i3S), University of Porto, Rua Alfredo Allen, 208, 4200-135, Porto, Portugal \\ ${ }^{\mathrm{d}}$ Life and Health Sciences Research Institute, School of Health Sciences, University of Minho, Braga, Portugal \\ ${ }^{\mathrm{e}}$ ICVS/3B's-PT Government Associate Laboratory, Braga, Guimarães, Portugal \\ ${ }^{\mathrm{f}}$ Unit of Biochemistry, Department of Biomedicine, Faculty of Medicine of University of Porto, Alameda Professor Hernâni Monteiro, 4200-319, Porto, Portugal \\ ${ }^{\mathrm{g}}$ Department of Molecular Pahology and Immunology, Abel Salazar Biomedical Sciences Institute (ICBAS), University of Porto, Rua de Jorge Viterbo Ferreira, 228, 4050- \\ 313, Porto, Portugal
}

\section{A R T I C L E I N F O}

\section{Keywords:}

Cell-penetrating peptides

CPP2

Thiazole

MCF-7

Caco-2

\begin{abstract}
A B S T R A C T
Cancer treatment is one of the major fields of interest for the scientific community. Investment in cancer research is costly but essential to provide patients with more effective and safe treatments. In this project, we describe the synthesis and characterization of new thiazole derivatives coupled to CPP2, a cell-penetrating peptide (CPP) reported for colon cancer cells. Using a human adenocarcinoma-derived cell line (Caco-2), these new CPPs were evaluated for antiproliferative $\left({ }^{3} \mathrm{H}\right.$-thymidine incorporation) and cytotoxic effect (extracellular lactate dehydrogenase activity). One of these derivatives, the BTZCA thiazole compound and its peptide-conjugated (BTZCACPP2) also showed the ability to decrease tumour cell viability and proliferation, with potential cytotoxic effect against human breast cancer MCF-7 cells. Then, cytotoxicity studies were developed against J774, L929 and THP1 cell lines and this new family showed no significant cytotoxicity, when compared to their counterparts alone (BTZCA and CPP2). The use of smaller CPP conjugated with this family of derivatives can be also considered in future for the development of new drugs to cancer therapy.
\end{abstract}

\section{Introduction}

Cancer treatment is one of the major challenges of science since tumour therapeutics lacks specificity and selectivity, presenting many adverse effects also in normal cells. To overcome this problem, targetspecific drug delivery system as cell-penetrating peptides (CPPs) represent a good alternative. CPPs are short peptides with less than 30 amino acids (mostly basic, positively charged amino acids) and have the ability to translocate through the cell membrane and deliver a variety of cargoes (Chiu et al., 2004; Fawell et al., 1994; Johnson et al., 2008; Rothbard et al., 2000; Zorko and Langel, 2005; Vale et al., 2017a). CPPs are already in use in cancer therapy, both to deliver chemotherapeutic drugs to cells (Tan et al., 2006) as well as to deliver pro-apoptotic proteins (Johansson et al., 2008). One of these peptides, CPP2 (Fig. 1) was recently reported to penetrate preferentially in LoVo human colon adenocarcinoma cells, as compared to other tumour cell lines (Kondo et al., 2012). Another study, using the colorectal cancer
(CRC) cell lines HCT116 and SW480 and a normal hepatic cell line, concluded that CPP2 selectively penetrates CRC cells, showing no significant cytotoxicity. As p16 mRNA expression is absent in tumour cell lines of various origins (Goto et al., 2010; Herman et al., 1995; Pinyol et al., 1998), the authors synthesized an antitumor peptide by coupling CPP2 to the minimal inhibitory sequence of p16 (p16MIS) that has the ability to restore the lost p16 function via the GPG sequence, for targeting CRC cells. Compared to CPP2 and p16MIS, the conjugated CPP2p16MIS proved to be a selective cytotoxic delivery system in vitro. The authors concluded that CPP2 has the potential for peptide-based in vivo molecular delivery in CRC. However, the CPP2 mechanism for CRC therapy remains unknown (Wang et al., 2016).

Our research group recently explored the structure-activity relationship of molecules containing thiazole moiety in drug development and synthesized new derivatives with amino acids and 2-amino-5-bromothiazole (Vale et al., 2017b). Several studies have used the Caco2 cell line as a model for CRC cells and screened thiazole derivatives for

\footnotetext{
* Corresponding author. Laboratory of Pharmacology, Department of Drug Sciences, Faculty of Pharmacy of University of Porto, Rua de Jorge Viterbo Ferreira, 228, 4050-313, Porto, Portugal.

E-mail address: nuno.vale@ff.up.pt (N. Vale).
} 


\section{CPP2 Asp-Ser-Leu-Lys-Ser-Tyr-Trp-Tyr-Leu-GIn-Lys-Phe-Ser-Trp-Arg}

\section{BTZ5CA-CPP2}

\section{BTZCA-CPP2}

\section{BenzoTZ-C2-CPP2}<smiles>O=C(NC(=O)c1cnc(Br)s1)c1ccccc1</smiles><smiles>O=C1N=CC(c2ncc(Br)s2)N1</smiles>

\section{$\mathrm{BTZ-C2-CPP2}(\mathrm{X}=\mathrm{Br})$ MTZ-C2-CPP2 $\left(X=\mathrm{CH}_{3}\right)$ NTZ-C2-CPP2 $\left(X=\mathrm{NO}_{2}\right)$}

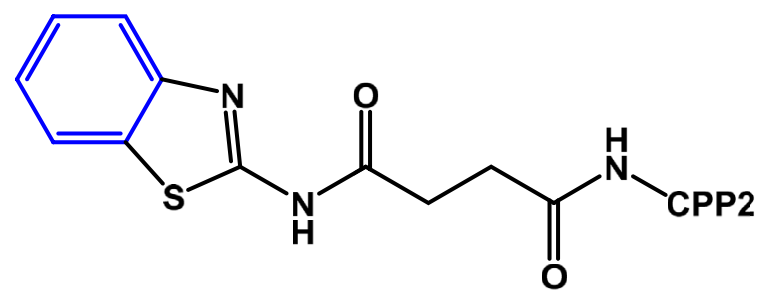<smiles>[X]c1cnc(NC(=O)CCC(=O)NC(=O)c2ccccc2)s1</smiles>

Fig. 1. Structure of the main compounds synthesized in this project. All compounds were synthesized by SPPS, analysed by HPLC and LC/MS and purified by MPLC

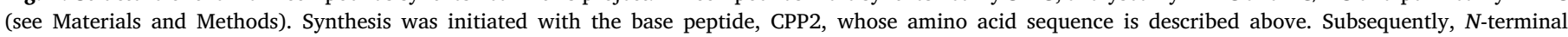

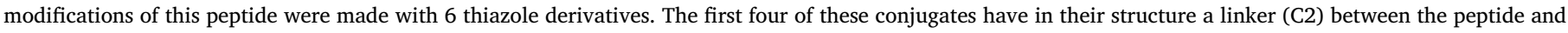
the thiazole derivative, while the other two do not have this structure. These compounds were all studied in Caco-2 cells for their anti-tumour effect.

antiproliferative and cytotoxic effect (Brockmann et al., 2014; Özkay et al., 2016; Parrino et al., 2017). Our group has also used this cell line to investigate the anticancer (antiproliferative and cytotoxic) effect of compounds in relation to CRC (Gonçalves et al., 2011).

In the present manuscript, we report the synthesis of novel CPP2thiazole conjugates (Fig. 1) and the evaluation of their anticarcinogenic properties by using the Caco- 2 cell line. We used six different thiazole conjugates: 5-bromothiazole (BTZ), 2-amino-5-nitrothiazole (NTZ), 2amino-5-methylthiazole (MTZ), 2-aminobenzothiazole (BenzoTZ), 5bromothiazole-2-carboxylic acid (BTZCA) and 2-bromothiazole-5-carboxylic acid (BTZ5CA). Of these, the first four were coupled to CPP2 by using a linker (succinic anhydride); in contrast, BTZCA and BTZ5CA were directly coupled to CPP2. We have found that BTZCA was the most effective peptide-conjugated thiazole derivative in decreasing cell viability and proliferation. The study of colon-modified CPP2 reported in this manuscript was promising but, in our view, the introduction of a thiazolic structure could provide additional data in tumour cells. Thus, and according to the literature, new thiazole derivatives were developed and investigated their cytotoxicy effects on A549 human lung adenocarcinoma, MCF-7 human breast adenocarcinoma and NIH/3T3 mouse embryonic fibroblast cell lines using MTT assay (Kaplancikli et al., 2017). In this work was reported a notable anticancer activity and selectivity of one compound on MCF-7 cell line, that can be attributed to multiple metalloproteinases inhibition potential (Kaplancikli et al., 2017). The best compound tested against Caco-2 (BTZCA-CCP2) was then evaluated on MCF-7 cell line, and the results were surprisingly better than BTZCA or CPP2. These results suggest that these new conjugates could be a good starting point for the development of peptide-based molecular delivery systems in cancer therapy.

\section{Materials and methods}

\subsection{Reagents, solvents and equipment}

All solvents used in this study were of analytical grade. Reagents and solvents were purchased from Novabiochem (Fmoc-amino acids and Fmoc-Rink Amide MBHA resin), Merck (TFA and other solvents) and Sigma-Aldrich (coupling agents, piperidine, DIEA and thiazole 
derivatives).

\subsection{Peptide purification}

Peptide purification was accomplished using a preparative mediumpressure liquid chromatography (MPLC) column packed with octadecyl carbon chain (C18)-bonded silica as the stationary phase. The purified products were analysed by reverse phase high-pressure liquid chromatography (RP-HPLC) and high resolution Mass Spectrometer attached to a Liquid Chromatography system (LC/MS/DAD) with Electrospray (ESI) ion source (Thermo Scientific LTQ Orbitrap XL. Purified peptide solutions were frozen and subsequently lyophilized, and the resulting peptide powders kept at $-20^{\circ} \mathrm{C}$ until used.

\subsection{Synthesis of CPP2}

We used a resin with a $0.38 \mathrm{mmol} / \mathrm{g}$ loading capacity and were performed with at $0.20 \mathrm{mmol}$ scale. The dry resin was transferred into the syringe and was conditioned in DMF for $20 \mathrm{~min}$. After that time, DMF was rejected and the resin was swelled in DCM for another 15 min. The initial deprotection step was carried out using $20 \%$ piperidine in DMF ( $3 \mathrm{ml}, 1 \times 1 \mathrm{~min}+1 \times 20 \mathrm{~min}$ ). After the deprotection, the resin was washed with DMF ( $3 \mathrm{ml}, 3 \times 1 \mathrm{~min})$ and DCM $(3 \mathrm{ml}, 3 \times 1 \mathrm{~min})$ and a Ninhydrin test was performed. Upon a positive Ninhydrin test the construction of the peptide chain was initiated. Amino acids (AA) were activated in solution for $5 \mathrm{~min}$ before being transferred to the syringe with a solution of Fmoc-AA-OH (5 eq.), coupling agent HBTU (5 eq.) and base DIEA (10 eq.) in DMF. The activated amino acid solution was then transferred to the reaction vessel to react with the previously deprotected resin or peptidyl-resin for $1 \mathrm{~h}$, under stirring. After this time, the peptidyl-resin was washed with DMF ( $3 \mathrm{ml}, 3 \times 1 \mathrm{~min}$ ) and DCM $(3 \mathrm{ml}, 3 \times 1 \mathrm{~min}$ ) and a Kaiser test was performed. When the Kaiser test was negative, the following deprotection step was carried out, using the deprotection solution $(20 \%$ piperidine in DMF $(3 \mathrm{ml}$, $1 \times 1 \mathrm{~min}+1 \times 20 \mathrm{~min}$ ). Once deprotection was completed, the resin was washed again with DMF ( $3 \mathrm{ml}, 3 \times 1 \mathrm{~min})$ and DCM $(3 \mathrm{ml}$, $3 \times 1 \mathrm{~min}$ ) and another Kaiser test was performed. When the deprotection was confirmed by a positive Kaiser test, the next Fmoc-AA-OH was coupled following the same aforementioned conditions. The peptide sequence was completed by repeating the cycles of coupling of Fmoc amino acids and deprotection steps. When the peptide sequence was completed and after the final deprotection, the peptidyl-resin was cleaved with a cleavage cocktail containing 95\% TFA, 2.5\% $\mathrm{H}_{2} \mathrm{O}$ and $2.5 \%$ thioanisole (TIS) $(\mathrm{v} / \mathrm{v})$. Then, the dry peptidyl-resin was transferred to $15 \mathrm{ml}$ Falcon tubes in $100 \mathrm{mg}$ portions and $1 \mathrm{ml}$ of cleavage cocktail was added to each portion. The tubes were left under orbital stirring for $2 \mathrm{~h}$ at room temperature. After that time, the peptide should be soluble in the solution and so the content of the tubes was filtered on a D4 funnel previously rinsed with TFA, and the resin beads were washed with TFA. The filtrate, containing the soluble peptide, was transferred to new Falcon tubes in $1 \mathrm{ml}$ portions and $14 \mathrm{ml}$ of cold tert-butyl methyl ether were added to each tube. After slightly shaking the tubes, they were cooled to $-22{ }^{\circ} \mathrm{C}$ for about $8 \mathrm{~min}$ and then centrifuged at $1301 \mathrm{~g}$ for $7 \mathrm{~min}$ at $-5^{\circ} \mathrm{C}$. The ether was carefully rejected and "fresh" ether was added again. The addition of ether and centrifugation were repeated 3 more times and finally the tubes were left in a vacuum desiccator until the crude peptide was dry. Dry peptide pellets were then solubilized in $10 \%$ aqueous acetic acid and analysed by HPLC and LCMS. CPP2 was then purified by RP-MPLC, using ACN in water with $0.05 \%$ TFA as eluent, in gradient mode (15-45\% of ACN).

\subsection{CPP2-thiazole conjugates synthesis}

\subsubsection{Synthesis of BTZ-C2-CPP2}

The last amino acid of the base sequence of CPP2 was deprotected and a Kaiser test was also performed. When the deprotection was confirmed by a positive Kaiser test, a linker (C2) was coupled to this sequence. This step was carried out using succinic anhydride (10 eq.) and pyridine $(2 \mathrm{ml})$ for $1 \mathrm{~h}$, under stirring. After this step, the resin was washed with DMF ( $3 \mathrm{ml}, 3 \times 1 \mathrm{~min})$ and DCM $(3 \mathrm{ml}, 3 \times 1 \mathrm{~min})$ and the BTZ (5 eq.) was coupled using the coupling agents HATU (5 eq.) and HOAt (5 eq.) and base DIEA (10 eq.) in DMF overnight, under stirring. Upon synthesis, the conjugate was cleaved and analysed by HPLC and LC-MS. BTZ-C2-CPP2 was then purified by RP-MPLC, using ACN in water with $0.05 \%$ TFA as eluent, in gradient mode (15-40\% of ACN).

\subsubsection{Synthesis of NTZ- and MTZ-C2-CPP2}

The last amino acid of the base sequence of CPP2 was deprotected and a Kaiser test was performed. When the deprotection was confirmed by a positive Kaiser test, a linker (C2) was coupled to this sequence. This step was carried out using succinic anhydride (10 eq.) and pyridine $(2 \mathrm{ml})$ for $1 \mathrm{~h}$, under stirring. After this step, the resin was washed with $\operatorname{DMF}(3 \mathrm{ml}, 3 \times 1 \mathrm{~min})$ and DCM $(3 \mathrm{ml}, 3 \times 1 \mathrm{~min})$ and divided in two parts. The 2-amino-5-nitrothiazole (NTZ) was coupled to one half and the 2-amino-5-methylthiazole (MTZ) to another, using the coupling agent TBTU (5 eq.) and base DIEA (10 eq.) in DMF for $2 \mathrm{~h}$, under stirring. Upon synthesis, the conjugates were cleaved and analysed by HPLC and LC-MS. NTZ- and MTZ-C2-CPP2 were then purified by RPMPLC, using ACN in water with $0.05 \%$ TFA as eluent, in gradient mode (15-40\% of ACN).

\subsubsection{Synthesis of BenzoTZ-C2-CPP2}

A suspension of BenzoTZ $(0.2500 \mathrm{~g})$ and C2 (2.4 eq.) in DMF ( $3 \mathrm{ml})$ was prepared at room temperature under magnetic stirring. DIEA (2 eq.) was added and allowed to react under these conditions for $24 \mathrm{~h}$. The reaction was monitored by TLC using dichloromethane/acetone 4:1 as the eluent. Analyzes were made for ESI-MS, the expected compound was confirmed to be obtained and column purification was carried out. The compound was then solubilized in water/methanol and lyophilized. Out of the syringe, in a small bottle, 2 eq. of purified BenzoTZ-C2, 2 eq. of PyBOP and 4 eq. of DIEA were placed together. Then this solution was placed in the syringe and left overnight under shaking. After $24 \mathrm{~h}$, the resin was cleaved and analysed by HPLC and LC-MS. BenzoTZC2-CPP2 was then purified by RP-MPLC, using ACN in water with $0.05 \%$ TFA as eluent, in gradient mode (15-40\% of ACN).

\subsubsection{Synthesis of BTZCA- and BTZ5CA-CPP2}

The last amino acid of the base sequence of CPP2 was deprotected and a Kaiser test was performed. When the deprotection was confirmed by a positive Kaiser test, the resin was washed with DMF $(3 \mathrm{ml}$, $3 \times 1 \mathrm{~min})$ and DCM ( $3 \mathrm{ml}, 3 \times 1 \mathrm{~min})$ and divided in two halves. Then the BTZCA (5 eq.) and the BTZ5CA (5 eq.) were coupled using the coupling agent TBTU (5 eq.) and base DIEA (10 eq.) in DMF for $2 \mathrm{~h}$, under stirring. A Kaiser test was then performed to confirm the efficacy of the coupling. Upon synthesis, the conjugates were cleaved and analysed by HPLC and LC-MS. BTZCA and BTZ5CA-CPP2 were then purified by RP-MPLC, using ACN in water with $0.05 \%$ TFA as eluent, in gradient mode (15-40\% of ACN).

\subsection{Citotoxicity, antiproliferative and culture growth assays in Caco-2 and MCF-7 cells}

\subsubsection{Cell culture and treatment}

The Caco- 2 cell line was obtained from the American Type Culture Collection (ATCC, Rockville, MD, USA) and was used between passage numbers $56-62$. Caco-2 cells (ATCC $37-\mathrm{HTB}$ ) were incubated at $37^{\circ} \mathrm{C}$ in a humidified atmosphere (95\% air; $5 \% \mathrm{CO}_{2}$ ) and were grown in Minimum Essential Medium (Sigma, St. Louis, MO, USA) supplemented with $15 \%$ fetal bovine serum, $25 \mathrm{mM}$ HEPES, 100 units/ml penicillin, $100 \mu \mathrm{g} \mathrm{ml}^{-1}$ streptomycin and $0.25 \mu \mathrm{g} \mathrm{ml}^{-1}$ amphotericin B. Culture medium was changed every 2-3 days and the culture was split every 7 days. For subculturing, the cells were removed enzymatically $(0.25 \%$ 
A

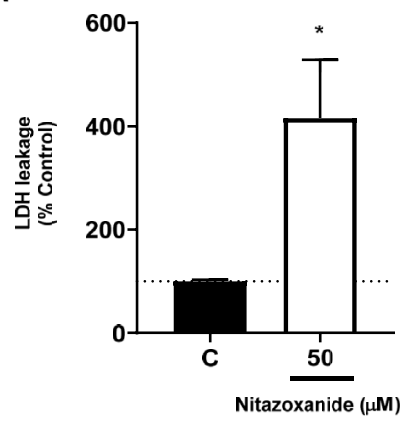

B

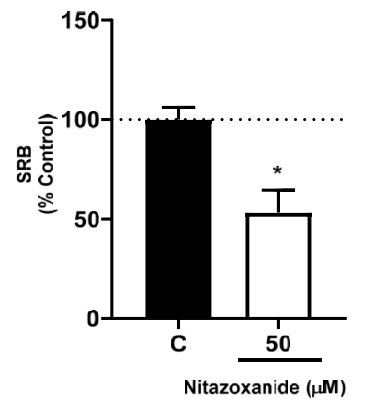

A

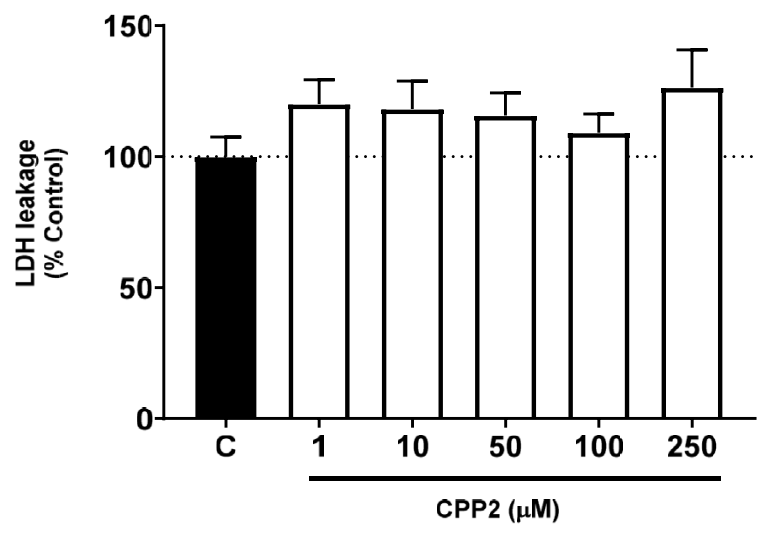

B

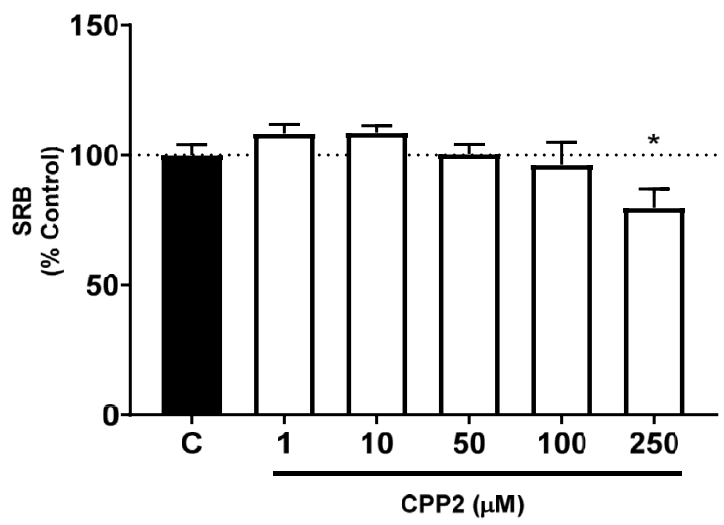

Fig. 2. Effect of a 24 h-exposure to $50 \mu \mathrm{M}$ of nitazoxanide upon Caco-2 cell viability (A) and cell mass (B). Cellular viability was determined by quantification of extracellular LDH activity, as described in Methods. Assessment of cell mass was determined by quantification of SRB, as also described in Methods. Results are presented as arithmetic means \pm S.E.M $(n=8) . *$ Significantly different from control $(\mathrm{P}<0.05)$.

trypsin-EDTA, $5 \mathrm{~min}, 37^{\circ} \mathrm{C}$ ), split 1:3, and subcultured in plastic culture dishes $\left(21 \mathrm{~cm}^{2} ; \varnothing 60 \mathrm{~mm}\right.$; Corning Costar, Corning, NY). For the experiments, the Caco- 2 cells were seeded on 24 -well plates $\left(2 \mathrm{~cm}^{2} ; \varnothing\right.$ $16 \mathrm{~mm}$; Corning Costar). For $24 \mathrm{~h}$ before the experiment, the cell medium was free of fetal bovine serum. Uptake and enzymatic studies were generally performed 14 days after the cells formed a monolayer.

Caco- 2 cells were treated for $24 \mathrm{~h}$ with CPP2 and all conjugates $(1-250 \mu \mathrm{M})$ except for BTZ-C2-CPP2 $(1-100 \mu \mathrm{M})$. At the end of the treatment period, proliferation, viability and assessment of cell mass studies were performed. Control cells were exposed to the respective solvent (water).

\subsubsection{Determination of cell proliferation rates}

Caco- 2 cells treated for $24 \mathrm{~h}$ with BTZCA-CPP2 $(100 \mu \mathrm{M})$ or the respective solvent (control) were incubated with ${ }^{3} \mathrm{H}$-thymidine $0.025 \mu \mathrm{Ci}$ / $\mathrm{ml}$ during the last $5 \mathrm{~h}$ of the treatment period. After removal of excess ${ }^{3} \mathrm{H}$-thymidine by a $10 \%$ trichloroacetic acid $\left(300 \mu \mathrm{l}\right.$ wash for $1 \mathrm{~h}$ at $4{ }^{\circ} \mathrm{C}$, drying for $30 \mathrm{~min}$ and addition of $280 \mu \mathrm{l}$ of $\mathrm{NaOH} 1 \mathrm{M}$ ), the incorporated ${ }^{3} \mathrm{H}$-thymidine was measured by liquid scintillometry.

\subsubsection{Determination of cellular viability}

After the treatment period $(24 \mathrm{~h})$ with CPP2 and CPP2-thiazole conjugates (1-250 $\mu \mathrm{M}$; except for BTZ-C2-CPP2 $(1-100 \mu \mathrm{M})$ ) or the respective solvent (control), cellular leakage of the cytosolic enzyme lactate dehydrogenase (LDH) into the extracellular (culture) medium was measured spectrophotometrically. In brief, extracellular LDH activity was quantified by measuring, in the culture medium, the oxidation of NADH at a wavelength of $340 \mathrm{~nm}$ during the reduction of pyruvate to lactate. Optical density values were determined for $2 \mathrm{~min}$, and the rate of NADH oxidation was then calculated. To determine total LDH activity, cells from control cultures were solubilized with $0.5 \mathrm{ml}$ $0.1 \%\left(\mathrm{v} / \mathrm{v}\right.$ ) Triton X-100 and placed for $30 \mathrm{~min}$ at $37^{\circ} \mathrm{C}$. The amount of $\mathrm{LDH}$ present in the extracellular medium was then calculated as a percentage of total LDH activity.

\subsubsection{Assessment of cell mass}

Caco- 2 cells treated for $24 \mathrm{~h}$ with CPP2 and CPP2-thiazole conjugates $(1-250 \mu \mathrm{M}$; except for BTZ-C2-CPP2 $(1-100 \mu \mathrm{M}))$ or the respective solvent (control) were fixated with a solution of trichloroacetic acid (TCA) $50 \%$ for $60 \mathrm{~min}$ at $4{ }^{\circ} \mathrm{C}$, followed by a wash step with $\mathrm{H}_{2} \mathrm{O}$. The plates were completely dried, and the cells were then dyed with a SRB solution ( $0.4 \%$ in $1 \%$ acetic glacial acid) (125 $\mu \mathrm{l} /$ well) for $15 \mathrm{~min}$, at room temperature. The excess of SRB was removed and the plates were washed with a solution of $1 \%$ acetic acid. Plates were dried once

Fig. 3. Effect of a 24 h-exposure to increasing concentrations of CPP2 upon Caco-2 cell viability (A) and cell mass (B). Cellular viability was determined by quantification of extracellular LDH activity, as described in Methods. Assessment of cell mass was determined by quantification of SRB, as also described in Methods. Results are presented as arithmetic means \pm S.E.M $(\mathrm{n}=8)$. * Significantly different from control $(\mathrm{P}<0.05)$.

again and the bound SRB was solubilized in Tris- $\mathrm{HCl}$ buffer $(10 \mathrm{mM}$ in $\left.\mathrm{H}_{2} \mathrm{O}, \mathrm{pH} 10.5\right)(375 \mu \mathrm{l} /$ well) under agitation for $2-3 \mathrm{~min}$. 96-Well plates were prepared with triplicates of the sample (1:20 dilution) (190 $\mu$ Tris $+10 \mu \mathrm{l}$ sample) and blank (Tris). The absorbance was measured at $540 \mathrm{~nm}$ in a microplate reader.

MCF-7 breast cancer cell line was purchased from ATCC (ATCC, USA). Cells were cultured in Dulbecco's Modified Eagle's Medium (DMEM) supplemented with stable L-glutamine, a mixture penicillin/ streptomycin (10,000 Units/ml and $10,000 \mu \mathrm{g} \mathrm{ml}^{-1}$, respectively) and $10 \%$ heat-inactivated Fetal Bovine Serum (FBS). Cells were incubated in a humidified atmosphere ( $95 \%$ air; $5 \% \mathrm{CO}_{2}$ ) at $37^{\circ} \mathrm{C}$. For cell cultures maintenance, cells were grown in monolayer and sub-cultivated twice a week. Cell passaging was done by trypsinization. All experiments were carried out with cells to $70-80 \%$ confluence and from batches with passage number lower than 30 . Cellular proliferation was expressed as the percentage of optic density (OD) relative to the OD of the control cells.

\subsubsection{Cell viability assay (MTT)}

MCF-7 cells were seeded in 96-well plates with $200 \mu \mathrm{l}$ per well with an initial cell density of $5.0 \times 10^{4}$ cells/well. Thereafter, cells were allowed to attach for $24 \mathrm{~h}$ and submitted to a $3 \mathrm{~h}$ serum starvation period. Cells were next either left untreated or treated with CPP2 
A

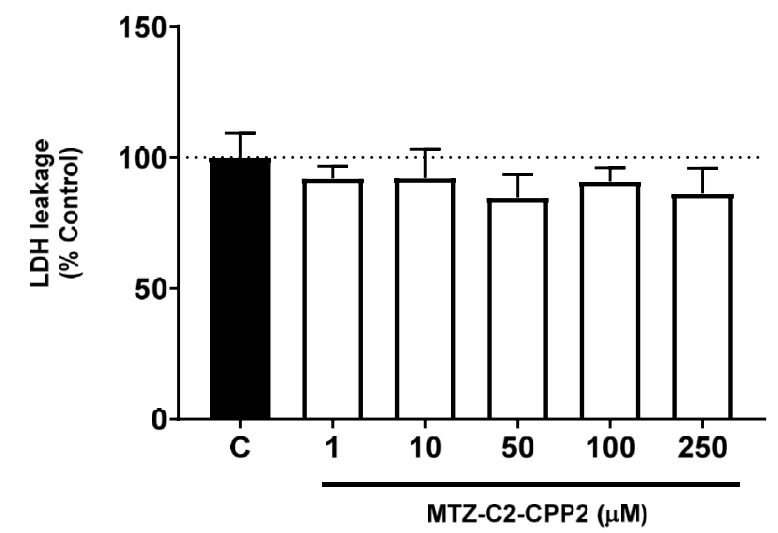

B

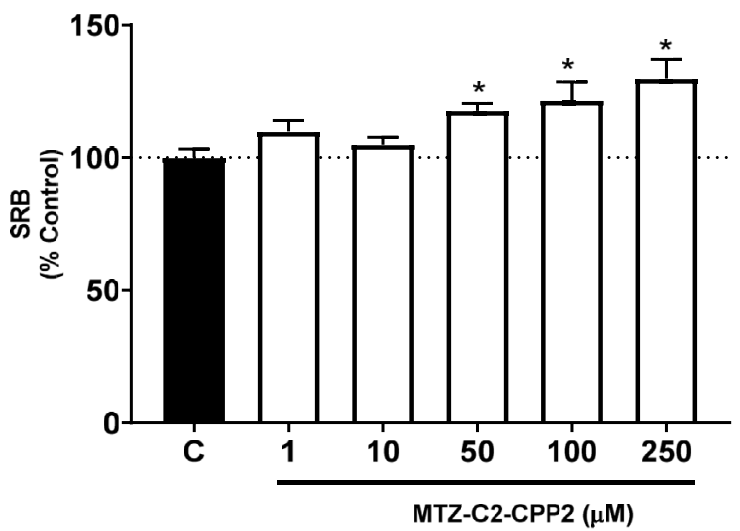

A

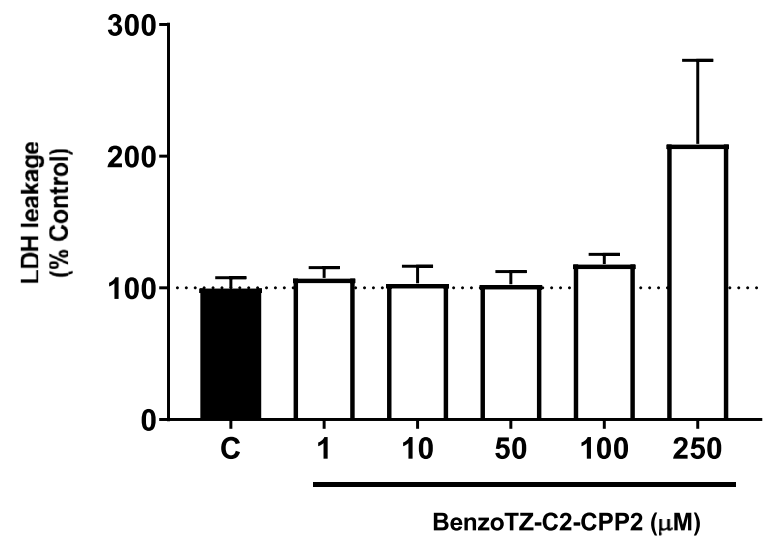

B

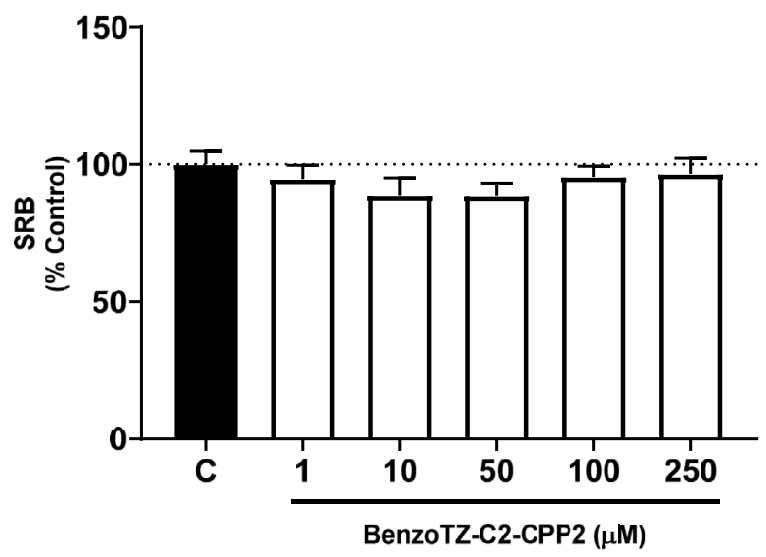

Fig. 4. Effect of a 24 h-exposure to increasing concentrations of MTZ-C2-CPP2 upon Caco-2 cell viability (A) and cell mass (B). Cellular viability was determined by quantification of extracellular LDH activity, as described in Methods. Assessment of cell mass was determined by quantification of SRB, as also described in Methods. Results are presented as arithmetic means \pm S.E.M $(\mathrm{n}=8)$. * Significantly different from control $(\mathrm{P}<0.05)$.

$(50 \mu \mathrm{M})$, BTZCA $(50 \mu \mathrm{M})$, BTZCA-CPP2 $(1-250 \mu \mathrm{M})$ or nitazoxanide $(50 \mu \mathrm{M})$ for $24 \mathrm{~h}$. During all the experimental period, cells were maintained at $37^{\circ} \mathrm{C}$ with $5 \% \mathrm{CO}_{2}$. A vehicle (cells exposed to DMSO at maximum final concentration of $0.1 \% \mathrm{v} / \mathrm{v}$ ) was also performed. All conditions were initiated and processed in parallel. After cell treatment, mitochondrial function was evaluated since mitochondrial dehydrogenases of living cells can reduce the MTT (yellow) to formazans, which are purple compounds. At the end of incubations, cell medium was removed and $100 \mu \mathrm{l} /$ well of MTT solution $(0.5 \mathrm{mg} / \mathrm{ml}$ in PBS) were added. Then, plates were incubated for $3 \mathrm{~h}$ protected from light. After this period, MTT solution was removed and DMSO (100 $\mu \mathrm{l} /$ well) was added to solubilize the formazan crystals. Absorbance was measured at $570 \mathrm{~nm}$ in an automated microplate reader (Sinergy HT, Biotek Instrumensts Inc, Vermont, USA). Results were compared with vehicle wells whose media of values was set to $100 \%$. All conditions were performed in triplicates.

\subsubsection{Protein determination}

The protein content of cell monolayers was determined as described by Bradford (Shen and He, 2007), using human serum albumin as standard.
Fig. 5. Effect of a 24 h-exposure to increasing concentrations of BenzoTZ-C2CPP2 upon Caco-2 cell viability (A) and cell mass (B). Cellular viability was determined by quantification of extracellular LDH activity, as described in Methods. Assessment of cell mass was determined by quantification of SRB, as also described in Methods. Results are presented as arithmetic means \pm S.E.M ( $\mathrm{n}=8-12)$. * Significantly different from control $(\mathrm{P}<0.05)$.

\subsection{Cytotoxicity assays in J744, L929 and THP1 cell lines}

\subsubsection{In vitro experimental design}

Frozen stocks of THP-1 (human monocytic cell line), J774 (murine macrophage-like cell line), and L929 (murine fibroblast cell line) were thawed and cultured in Dulbecco's Modified Eagle Medium (DMEM) supplemented with 10\% fetal bovine serum (Gibco), $2 \mathrm{mM} \mathrm{L-glutamine}$ (Gibco), $10 \mathrm{mM}$ HEPES (Gibco), and $1 \mathrm{mM}$ sodium pyruvate (Gibco). Cells were expanded in $175 \mathrm{~cm}^{2}$ flasks until $90 \%$ confluence. Cells were then plated in a 96-well microtiter plate $\left(1 \times 10^{5}\right.$ cells per well $)$ and left to rest for $4 \mathrm{~h}$. Cells were incubated for $24 \mathrm{~h}$ in the presence of 2 -fold serial dilutions of CPP2, BTZCA, BTZCA-CPP2 or DMSO equivalent as vehicle control.

\subsubsection{MTS assay}

Metabolic cell viability was measured using CellTiter 96 AQueous One Solution Cell Proliferation Assay - MTS (Promega) according to manufacturer's instructions. Briefly, the MTS assay is a colorometric assay based on the reduction of the MTS tetrazolium compound by NAD (P)H-dependent cellular oxidoreductase enzymes to generate a colored formazan dye that is soluble in cell culture media. The quantity of formazan product, measured by the amount of $490 \mathrm{~nm}$ absorbance, is 
A
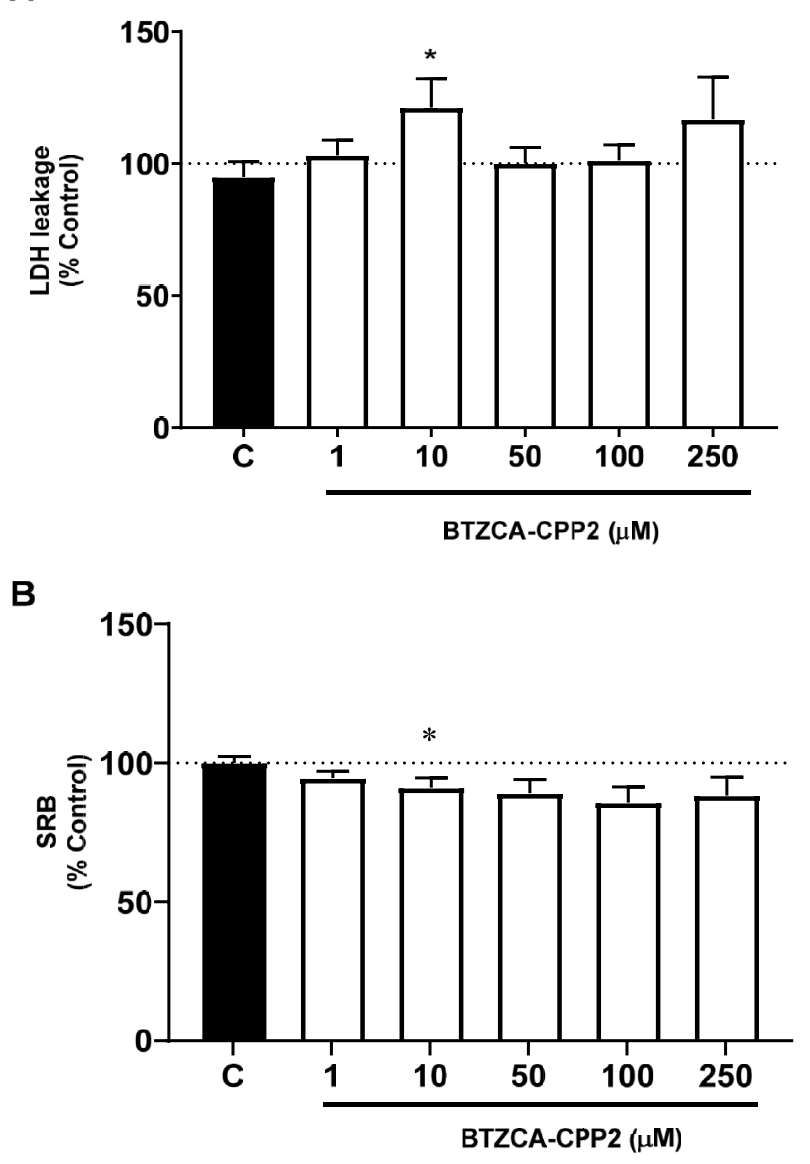

Fig. 6. Effect of a 24 h-exposure to increasing concentrations of BTZCA-CPP2 upon Caco-2 cell viability (A) and cell mass (B). Cellular viability was determined by quantification of extracellular LDH activity, as described in Methods. Assessment of cell mass was determined by quantification of SRB, as also described in Methods. Results are presented as arithmetic means \pm S.E.M ( $\mathrm{n}=8-12)$. * Significantly different from control $(\mathrm{P}<0.05)$.

directly proportional to the number of viable cells in culture.

\subsection{Statistical analysis}

Arithmetic means are given with S.E.M. Statistical significance of the difference between two groups was evaluated by the Student's $t$-test. Differences were considered to be significant when $\mathrm{P}<0.05$.

\section{Results}

\subsection{CPP2 and thiazole-CPP2 conjugates synthesis}

The first peptide to be synthetized, CPP2, was synthesized following the solid phase peptide synthesis methodology (SPPS, see materials and methods) with a Fmoc/Bzl protection scheme. This allows smoother synthesis conditions, the use of low danger solvents and usually of routine use in the laboratory. Confirmation of the peptide was obtained by HPLC and LC/MS by looking up the values corresponding to the proton charge distribution on the peptide; in this case peaks of $\mathrm{m} / \mathrm{z}$ were found at values of 1003.51, 669.34, 502.26 and 402.00 (Supplementary Fig. S2). Chromatograms as well as mass spectra are found in the supplementary info (Figs. S1-S14). After purification the

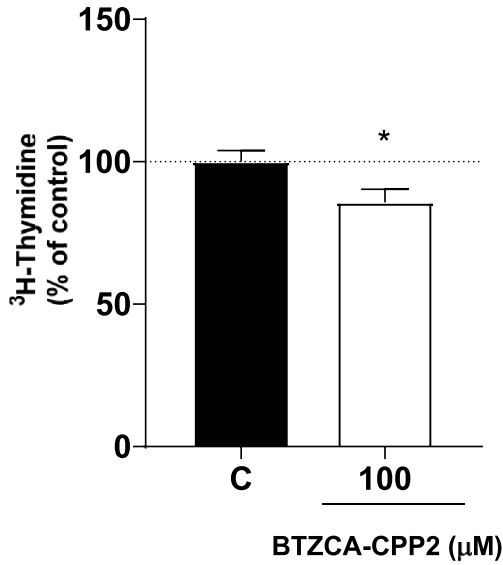

Fig. 7. Effect of a 24 h-exposure to $100 \mu \mathrm{M}$ of BTZCA-CPP2 upon Caco- 2 cell proliferation. Cellular proliferation was quantified by determination of ${ }^{3} \mathrm{H}$ thymidine incorporation, as also described in Methods. Results are presented as arithmetic means \pm S.E.M $(\mathrm{n}=6)$. * Significantly different from control $(\mathrm{P}<0.05)$.

peptide was purified by MPLC.

Synthesis of this peptide provided the starting point for the synthesis of the 6 conjugates proposed in this work (Fig. 1), which were all obtained by $N$-terminal modification of CPP2 peptide. Four of the conjugates had the similarity of having a linker (succinic anhydride, C2) between the thiazolic derivative (TZ) and CPP2. This linker was chosen because of its simple structure, small size and ability to establish two amide bonds when in its extended form, one at each end. Three of these thiazolic derivatives differed only in the 5th position of the thiazole ring, presenting groups as bromine (BTZ-C2-CPP2), methyl (MTZ-C2-CPP2) or nitro (NTZ-C2-CPP2). The last derivative of this family was composed of an additional benzene ring (BenzoTZ-C2-CPP2). The use of these thiazole derivatives enabled us to gauge the influence of 5 th ring position group on the activity of the derivative (since all remaining structure was the same) and the influence of an additional ring into the thiazole structure.

BTZ-like thiazole derivatives differed in the following: one of the derivatives was substituted at its 2 nd position with a carboxylic group (instead of an amine as in BTZ) but the bromo group at the 5th position of the ring was maintained. The second derivative was similar to the last one but with its groups in reversed positions i.e. the carboxylic group at its 5th position and the bromo substituent at its 2nd. Since these derivatives had a carboxylic group in their structure, the amide bond between these conjugates and the peptide was allowed without recourse of a linker. The use of these derivatives aimed at ascertaining the influence of the presence of the linker on the activity of the conjugate as well as on the influence of the position of the bromo substituent on the ring.

All conjugates were synthesized according to the methodology previously described and analysed by HPLC and LC-MS. After purification by MPLC, we could proceed to in vitro assays in four cell lines. All peptides were used with a very high degree of purity. The information about purity is associated to the chromatogram showed in the Support Information: CPP2 (93\%), BTZ-C2-CPP2 (100\%), NTZ-C2CPP2 (96\%), MTZ-C2-CPP2 (97\%), BenzoTZ-C2-CPP2 (96\%), BTZCAC2-CPP2 (96\%) and BTZ5CA-C2-CPP2 (98\%).

\subsection{In vitro assays}

Cell viability and proliferation assays were performed, as well as determination of protein synthesis rate by the cells. Cell viability was 
A

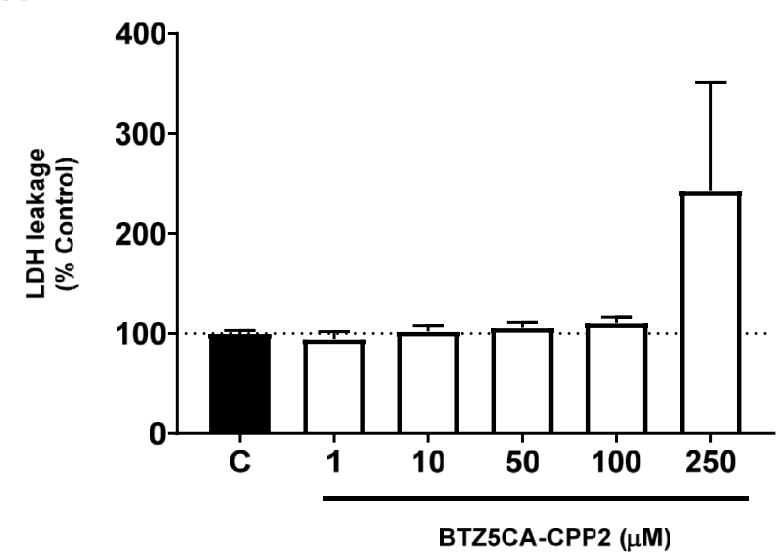

B

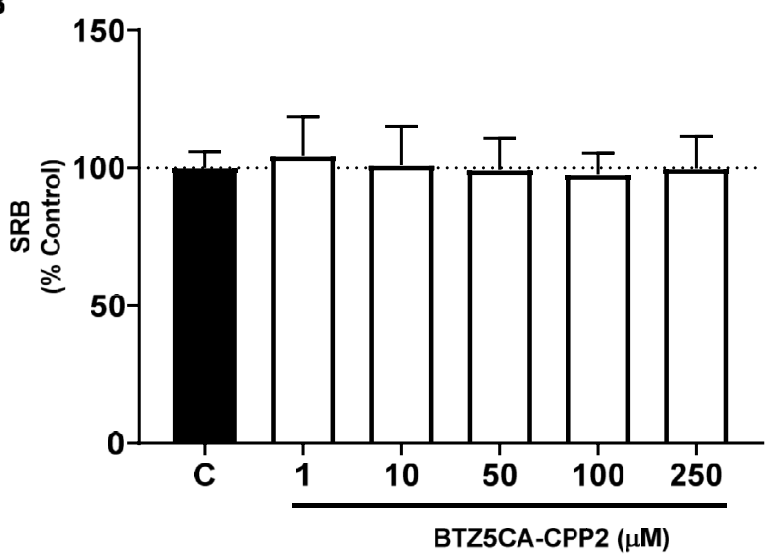

Fig. 8. Effect of a 24 h-exposure to increasing concentrations of BTZ5CA-CPP2 upon Caco-2 cell viability (A) and cell mass (B). Cellular viability was determined by quantification of extracellular LDH activity, as described in Methods. Assessment of cell mass was determined by quantification of SRB, as also described in Methods. Results are presented as arithmetic means \pm S.E.M ( $\mathrm{n}=8-12)$. * Significantly different from control $(\mathrm{P}<0.05)$.

assessed by quantification of the LDH enzyme in the extracellular medium of the cells. This enzyme is in the cytoplasm of the cells in their normal state. In cell death situation, the plasma membrane loses its integrity and this enzyme leaves the cytosol to the outside medium. Thus, the quantification is proportional to the rate of cell death and provides sustained information on cell viability.

Determination of protein synthesis rate by the cells may serve as a supplemental assay to that previously mentioned methodology since the lower the viability of the cells, the lower their protein synthesis rate. This determination was made using the SRB assay, which is an acid dye and is therefore able to bind to the basic amino acids found in the cell proteins. The higher the binding, the higher its spectrophotometric signal and the higher rate of protein synthesis.

Determination of cell proliferation rates was only performed for the most promising conjugate and aimed to determine the effect of the compound on cell replication rate. This technique is based on the incorporation of the radioactive thymidine by the daughter cells during mitosis; being a nucleotide naturally present in the DNA, when cells proliferate, this nucleotide will be incorporated in the new DNA daughter cell chains and will emit a signal that is directly proportional to the rate of proliferation.
A

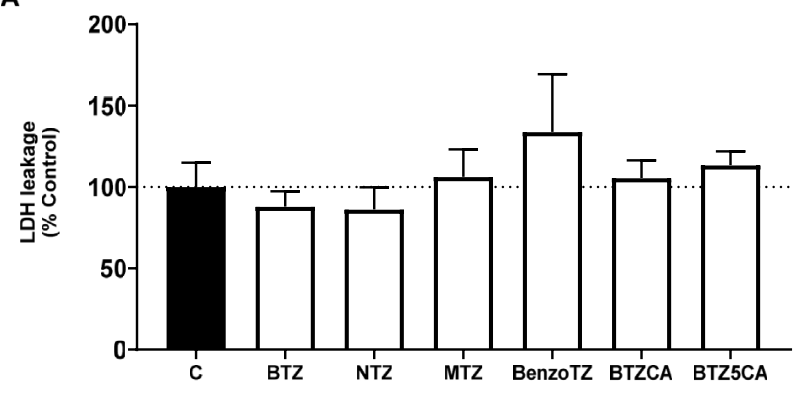

B

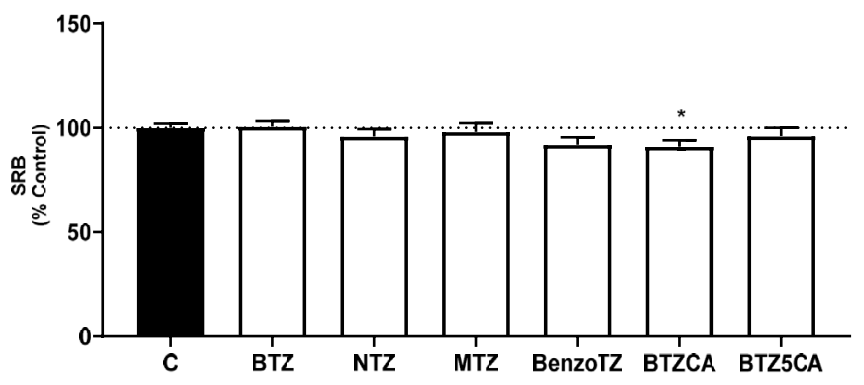

Fig. 9. Effect of a $24 \mathrm{~h}$-exposure to $50 \mu \mathrm{M}$ of different thiazole derivatives upon Caco-2 cell viability (A) and cell mass (B). Cellular viability was determined by quantification of extracellular LDH activity, as described in Methods. Assessment of cell mass was determined by quantification of SRB, as described in Methods. Results are presented as arithmetic means \pm S.E.M $(n=8)$. * Significantly different from control $(\mathrm{P}<0.05)$.

\subsubsection{Effect of nitazoxanide on cell viability and cell mass}

As a reference molecule, nitazoxanide was used as a positive control to validate the methodology used. Nitazoxanide has previously been proposed as a possible candidate for the treatment of CRC (Senkowski et al., 2015). As expected, in its presence, a decrease in cell viability and cell mass was found. Indeed, in the presence of nitazoxanide $(50 \mu \mathrm{M})$, an increase of about $300 \%$ in the percentage of extracellular LDH (Fig. 2A) and a decrease of up to $53 \%$ in the cell mass (Fig. 2B) was observed. So, the applicability of this methodology to the remaining compounds as well as the possibility of using this drug in the treatment of colon cancer was demonstrated.

\subsubsection{Effect of CPP2 on cell viability and cell mass}

CPP2 has been described as being specific for a cell line derived from colon adenocarcinoma, the LoVo cells. Another work has made an $N$-terminal modification in this peptide with a gene and demonstrated the selective delivery of this CPP (Kondo et al., 2012). Our objective was to know if CPP2 would have anti-tumour activity alone in relation to the cell line used in our study, the Caco- 2 cells, by performing the LDH and SRB assays. As shown in Fig. 3, a tendency to an increase in the percentage of extracellular LDH in the medium (Fig. 3A) as well as a decrease in cell mass (Fig. 3B), was observed in the presence of this compound. The ability of CPP2 to be incorporated by Caco- 2 cells as well as its intrinsic antitumor activity, although not as pronounced as with nitazoxanide, has been proven with these results.

\subsubsection{Effect of BTZ-C2-CPP2 on cell viability and cell mass}

Once the use of CPP2 in this cell type was validated, we proceeded to evaluate the effect of the remaining conjugates on Caco- 2 cells. For BTZ-C2-CPP2 (1-100 $\mu \mathrm{M})$, there were no notable differences in the LDH or SRB assays (data not shown). 
A
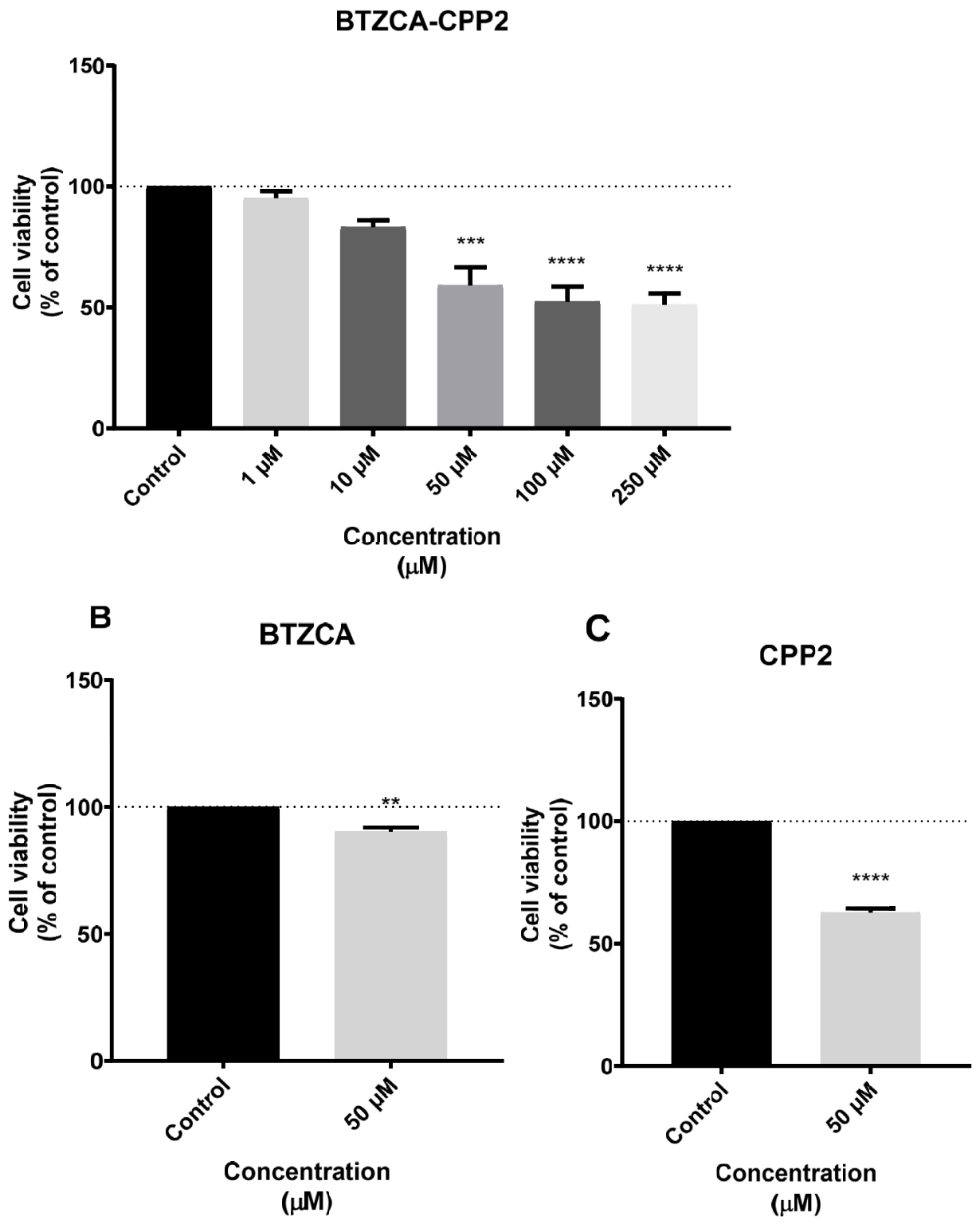

Fig. 10. Effect of cell viability with $24 \mathrm{~h}$-exposure to $1-250 \mu \mathrm{M}$ of BTZCA-CPP2 conjugate against MCF-7, as well BTZCA (50 $\mu \mathrm{M})$ and CPP2 (50 $\mu \mathrm{M})$, using MTT as assay. Results are presented as arithmetic means \pm S.E.M $(\mathrm{n}=6)$. * Significantly different from control $(\mathrm{P}<0.05)$.

\subsubsection{Effect of NTZ-C2-CPP2 on cell viability and cell mass}

NTZ-C2-CPP2 assays were performed for concentrations ranging from 1 to $250 \mu \mathrm{M}$. Both the SRB and the LDH test did not have very different results from the control (data not shown). So, no effect on cell mass and viability were found.

\subsubsection{Effect of MTZ-C2-CPP2 on cell viability and cell mass}

The effect of MTZ-C2-CPP2 conjugate was also evaluated for a concentration range of $1-250 \mu \mathrm{M}$. No effect was noticed in relation to cell viability (Fig. 4A). However, in the SRB assay, an increase in the SRB signal with the highest concentrations of MTZ-C2-CPP2 was observed (Fig. 4B). This conjugate thus presents an opposite behavior pattern in relation to cell mass to what was expected for a possible colon cancer therapy.

\subsubsection{Effect of BenzoTZ-C2-CPP2 on cell viability and cell mass}

The introduction of a benzene ring into the thiazolic ring structure appears to have no great impact in its activity, since no effect of the conjugate on cell viability (Fig. 5A) and cell mass (Fig. 5B) was found, although at $250 \mu \mathrm{M}$ concentration, a tendency to a decrease in cell viability was observed (Fig. 5A). One of the possible reasons may be related to the aggregation of peptides (Meli et al., 2008).

\subsubsection{Effect of BTZCA-CPP2 on cell viability and cell mass}

The last two conjugates had the particularity of being smaller given the lack of the linker and showed quite interesting anti-tumour effects. For BTZCA-CPP2 $(10 \mu \mathrm{M})$, a significant increase in the percentage of extracellular LDH (Fig. 6A), as well as a decrease of the SRB signal (Fig. 6B), was observed. At pharmacological level, these results are very important since they suggest that this conjugate could have anti-tumour 


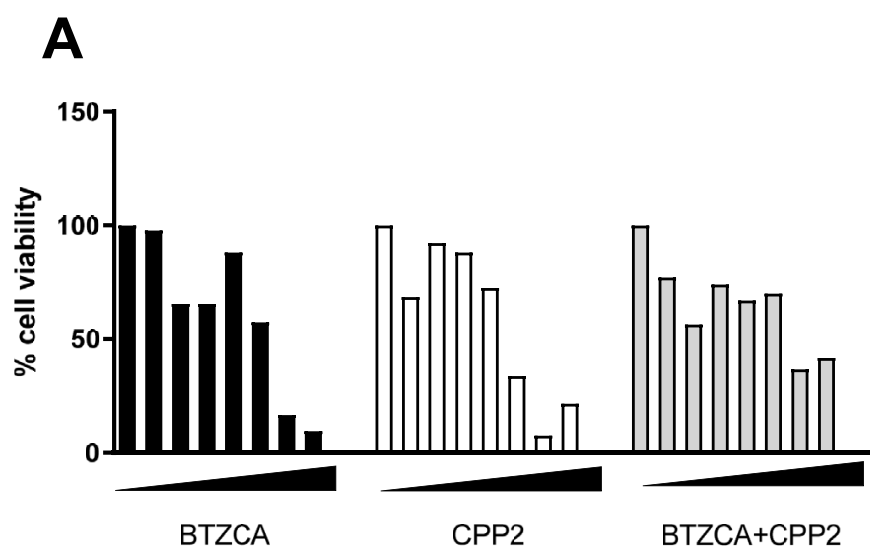

B

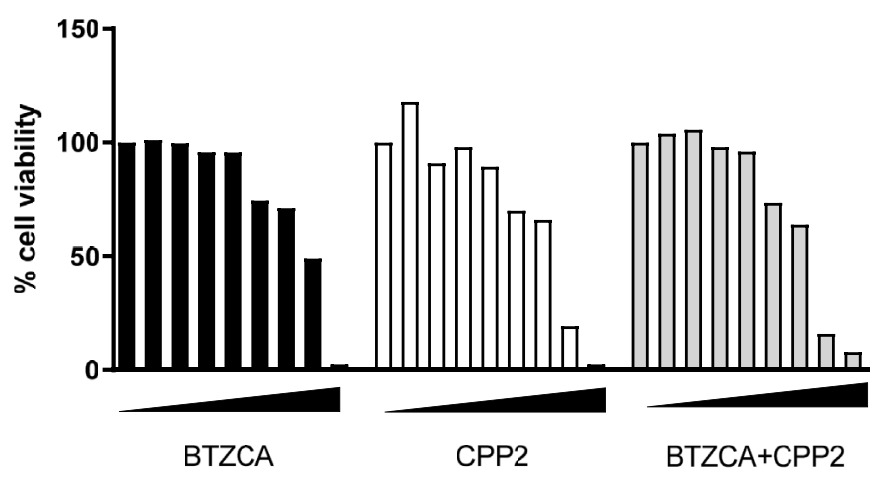

C

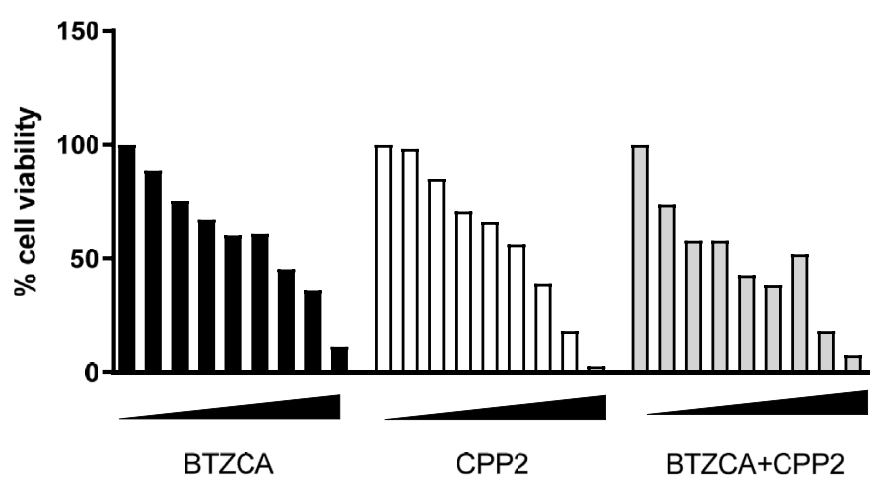

Fig. 11. Cell cytotoxicity to BTZCA, CPP2 and BTZCA-CPP2. Increasing concentrations of BTZCA, CPP2, and BTZCA-CPP2 [range 0-100 $\mu \mathrm{M}$ ] were added to wells with (A) J774, (B) THP1, and (C) L929 cells. After an incubation period of $24 \mathrm{~h}$, at $37^{\circ} \mathrm{C}$ with $5 \% \mathrm{CO}_{2}$, cell viability was determined using the MTS assay.

activity, even at lower concentrations.

3.2.7.1. Effect of BTZCA-CPP2 on cell proliferation rates. We decided to perform a cell proliferation assay to further characterize the effect of BTZCA-CPP2. At a concentration of $100 \mu \mathrm{M}$, a significant decrease in the amount of incorporated ${ }^{3} \mathrm{H}$-thymidine was found (Fig. 7). This proves that this compound has the ability to reduce the proliferation of these cells.

\subsubsection{Effect of BTZ5CA-CPP2 on cell viability and cell mass}

This conjugate (BTZ5CA-CPP2) did not cause significant changes in both cell viability (Fig. 8A) and cell mass (Fig. 8B), although a tendency to a decrease in cell viability could be observed (Fig. 8A).

\subsubsection{Effect of thiazole derivatives on cell viability and cell mass}

To determine if CPP2 introduction was advantageous, in vitro assays were performed to assess the effects of each of the thiazole derivatives used for the conjugate synthesis. The results obtained consistent with the results obtained with the conjugates, as there is a decrease in cell viability in the presence of BTZCA (at $50 \mu \mathrm{M}$ ) (Fig. 9A). Similarly, to the conjugates with thiazole moiety, these compounds did not affect cell viability (Fig. 9B). These results suggest this family of derivatives based on a thiazolic scaffold have some intrinsic anti-tumour activity.

\subsubsection{Effect of BTZCA, CPP2 and BTZCA-CPP2 on cell cancer line MCF-} 7

Three compounds were investigated for their cytotoxic effects on human breast adenocarcinoma, MCF-7. The potential inhibitory effects of the best candidate (BTZCA-CPP2) was increased when compared with parental and separated compounds (BTZCA and CPP2, Fig. 10).

\subsubsection{Effect of thiazole derivatives on cell viability}

Cytotoxicity studies of BTZCA, CPP2 and the BTZCA-CPP2 conjugate were also performed on J774 macrophages (Fig. 11A), THP-1 monocytes (Fig. 11B) and L929 fibroblasts (Fig. 11C). Despite the decrease in cell viability with increasing concentrations of each compound, due to the effect of DMSO-vehicle (data not shown), no significant differences in cell viability were observed between the addition of CPP2 or BTZCA, when compared to the BTZCA-CPP2 conjugate. Collectively, these results suggest that the introduction of CPP2 to thiazole derivatives does not affect cell viability.

\section{Discussion}

Cancer is one of the major causes of death in the world. The development of new, more specific and effective therapies for this disease is one of the priorities of many research groups. Colorectal cancer (CRC) is one of the most prevalent and widely studied cancers in the world and results from an accumulation of genetic and epigenetic changes in colon epithelial cells, which transforms them into adenocarcinomas. CRC is the third most frequently diagnosed cancer both in men and women and remains the second leading cause of cancer mortality in the United States, with an estimated 129,000 new cases expected for 2017 (Siegel et al., 2015). Despite all the advances that have been taken place in the battle against cancer over the past few decades, there are still limited advances in the outcome of CRC (Sporn, 1996), since current CRC treatments are not targeted to cancer cells and also affect normal cells. To promote efficient drug delivery, several approaches have been developed, such as microinjection, electroporation, liposomal formulation, and the use of viral vectors (Elmquist et al., 2001; Pujals and Giralt, 2008); however, all these techniques show poor cell specificity (Vivès et al., 1997). Also, the beneficial effects of many recent discovered potential therapeutic agents (such as proteins, nucleic acids, and drugs) are limited due to their inability to reach the appropriate targets as the passage of molecules through the cellular barriers must overcome the high resistance epithelial or endothelial cell membranes which block the passage of various compounds from the intestine and the circulating blood into the human body (Lindgren et al., 2004). This resistance results from the formation of tight junctions (TJs) between the cells that exclude paracellular passage of ions, peptides, and proteins (Anderson, 2001). In the last two decades, many studies have focused their attention on the development of novel CPPs or modification of known CPPs with the aim of improving their properties, namely their stability or specificity (Heitz et al., 2009). For cancer therapy, the cellular specificity of CPPs is particularly important in 
order to minimize the side effects in normal cells (Geisler and Chmielewski, 2009; Martín et al., 2010). Thus, the demand for CPPs that are specific and non-toxic is essential for cancer treatment to be effective. Recently, some strategies have been developed, based in the combination of a tumour homing peptide with a CPP, leading to the formation of a chimeric peptide with tumour cell specificity that can carry therapeutic agents into the cells (Munyendo et al., 2012).

Our research group successfully synthesized a new family of conjugates using a pentagonal scaffold coupled to a CPP, CPP2, with known activity. We have made $N$-terminal modifications of this peptide with 6 different thiazole derivatives and we described the methodologies used for the synthesis for these compounds. Six conjugates with high degrees of purity were obtained in an amount that agrees with the methodology employed. The intrinsic anti-tumour activity of CPP2 was studied in Caco- 2 cell line. The Caco- 2 cell monolayer is a well-characterized human colon adenocarcinoma cell line that is used for high-throughput screening of drug permeability in the pharmaceutical industry (Sun et al., 2008). The anti-tumour activity of CPP2 has been proved as well as the possibility of the use of nitazoxanide in the therapy of CRC. Also, we observed that changes on the 5th position substituent group of the thiazole ring as well as the introduction of an additional rings influences the activity of the conjugates. The linker between CPP2 and the thiazolic derivative is not advantageous since conjugates lacking this ring have an improved anti-cancer activity. We have exploited the potential of this family of thiazole derivatives for the treatment of CRC cancer. Importantly, this conjugate does not present increased cytotoxicity when compared to the thiazole derivative or peptide alone.

This work may serve as a starting point for future projects that seek to exploit the cancer therapeutic potential of CPPs or of this pentagonal scaffold. As a continuation of this project, we propose the use of other CPPs conjugated with these derivatives, preferably with smaller sizes or even to use these conjugates in other cell lines, since they may not present activity for Caco-2 cells but be active against other cell types. Overall, this investigation project proved to be a very promising new strategy/approach. In the future, different CPPs and different molecules could be conjugated to improve cancer (and even other diseases) treatment and diminish side effects. The cell viability assay showed potential activity of BTZCA-CPP2 for breast cancer cell. We believe that is possible the relationship between overexpression of matrix metallopreteinases (MMPs) and tumour invasion/metastasis, and BTZCA-CPP2 can be a MMP inhibitor as anticancer drug. Additional studies are still required to more accurately explain the mechanism of this inhibition pathway for this compound.

However, it has been showed in this project that CPP2 activity can be improved with the introduction of BTZCA, when compared with previous work with CPP2 on MCF-7, that did not show significant permeation (Kondo et al., 2012).

\section{Conclusion}

We also propose to investigate the effect of the conjugation of this family of thiazole derivatives with other type of vectors, such as nanoparticles. This work further confirmed that nitazoxanide could be a candidate for treatment of CRC, since its anticarcinogenic activity in these cells was proven. This type of work is very important in that it can help and improve cancer treatments, as well in decrease the side effects associated with these types of therapies.

\section{Conflicts of interest}

None of the authors have any relevant conflicts of interest or disclosures.

\section{Acknowledgments}

This work was financed by FEDER - Fundo Europeu de
Desenvolvimento Regional funds through the COMPETE 2020 Operacional Programme for Competitiveness and Internationalisation (POCI), Portugal 2020, and by Portuguese funds through FCT Fundação para a Ciência e a Tecnologia, in the framework of the project "Institute for Research and Innovation in Health Sciences" (POCI-010145-FEDER-007274)." This work was also financed by FCT and FEDER (European Union), through project IF/00092/2014/CP1255/CT0004. NV thanks FCT by IF position, DQB-Faculty of Sciences from University of Porto, for support in peptide synthesis, and Fundação Manuel António da Mota by support Nuno Vale Lab. DD thanks FCT for PhD grant with ref. SFRH/BD/140734/2018. AGF and JP were involved in the cytotoxicity assays, which were developed within the scope of the projects NORTE-01-0145-FEDER-000013 and NORTE-01-0145-FEDER000023, supported by the Northern Portugal Regional Operational Programme (NORTE 2020), under the Portugal 2020 Partnership Agreement through FEDER. This work was also financed through the Competitiveness Factors Operational Programme (COMPETE) and by national funds, through FCT, under the scope of the project POCI-010145-FEDER-007038. AGF would also like to acknowledge FCT for the post-doc fellow SFRH/BPD/112903/2015. The contents of this report are solely the responsibility of the authors and do not necessarily represent the official views of the FCT or FMAM.

\section{Appendix A. Supplementary data}

Supplementary data to this article can be found online at https:// doi.org/10.1016/j.ejphar.2019.172554.

\section{References}

Anderson, J.M., 2001. Molecular structure of tight junctions and their role in epithelial transport. News Physiol. Sci. 16, 126-130. https://doi.org/10.1083/jcb.134.4.1031.

Brockmann, A., Strittmatter, T., May, S., Stemmer, K., Marx, A., Brunner, T., 2014. Structure-function relationship of thiazolide-induced apoptosis in colorectal tumor cells. ACS Chem. Biol. 9, 1520-1527. https://doi.org/10.1021/cb500209a.

Chiu, Y.L., Ali, A., Chu, C.Y., Cao, H., Rana, T.M., 2004. Visualizing a correlation between siRNA localization, cellular uptake, and RNAi in living cells. Chem. Biol. 11, 1165-1175. https://doi.org/10.1016/j.chembiol.2004.06.006.

Elmquist, A., Lindgren, M., Bartfai, T., Langel, Ü., 2001. VE-Cadherin-Derived cell-penetrating peptide, pVEC, with carrier functions. Exp. Cell Res. 269, 237-244. https:// doi.org/10.1006/excr.2001.5316.

Fawell, S., Seery, J., Daikh, Y., Moore, C., Chen, L.L., Pepinsky, B., Barsoum, J., 1994. Tatmediated delivery of heterologous proteins into cells. Proc. Natl. Acad. Sci. 91, 664-668. https://doi.org/10.1073/pnas.91.2.664.

Geisler, I., Chmielewski, J., 2009. Cationic amphiphilic polyproline helices: side-chain variations and cell-specific internalization. Chem. Biol. Drug Des. 73, 39-45. https:// doi.org/10.1111/j.1747-0285.2008.00759.x.

Goncalves, P., Araujo, J.R., Joao Pinho, M., Martel, F., 2011. In vitro studies on the inhibition of colon cancer by butyrate and polyphenolic compounds. Nutr. Canc. Int. J. 63, 282-294. Pii: 931767555. https://doi.org/10.1080/01635581.2011.523166.

Goto, T., Mizukami, H., Shirahata, A., Yokomizo, K., Kitamura, Y.O.H., Sakuraba, K., Saito, M., Ishibashi, K., Kigawa, G., Nemoto, H., Sanada, Y., Hibi, K., 2010. Methylation of the 16 gene is frequently detected in lymphatic-invasive gastric cancer. Anticancer Res. 30, 2701-2703.

Heitz, F., Morris, M.C., Divita, G., 2009. Twenty years of cell-penetrating peptides: from molecular mechanisms to therapeutics. Br. J. Pharmacol. 157, 195-206. https://doi. org/10.1111/j.1476-5381.2009.00057.x.

Herman, J.G., Merlo, A., Mao, L., Lapidus, R.G., Issa, J.P., Davidson, N.E., Sidransky, D., Baylin, S.B., 1995. Inactivation of the CDKN2/p16/MTS1 gene is frequently associated with aberrant DNA methylation in all common human cancers. Cancer Res. 55, 4525-4530.

Johansson, H.J., El-Andaloussi, S., Holm, T., Mäe, M., Jänes, J., Maimets, T., Langel, Ü., 2008. Characterization of a novel cytotoxic cell-penetrating peptide derived from p14ARF protein. Mol. Ther. 16, 115-123. https://doi.org/10.1038/sj.mt.6300346.

Johnson, L.N., Cashman, S.M., Kumar-Singh, R., 2008. Cell-penetrating peptide for enhanced delivery of nucleic acids and drugs to ocular tissues including retina and cornea. Mol. Ther. 16, 107-114. https://doi.org/10.1038/sj.mt.6300324.

Kaplancikli, Z.A., Altıntop, M.D., Atli, O., Sever, B., Baysal, M., Temel, H.E., Demirci, F., Ozdemir, A., 2017. Synthesis and evaluation of a new series of thiazole derivatives as potential antitumor agents and MMP inhibitors. Anti Cancer Agents Med. Chem. 17, 674-681. https://doi: 10.2174/1871520616666160802113620.

Kondo, E., Saito, K., Tashiro, Y., Kamide, K., Uno, S., Furuya, T., Mashita, M., Nakajima, K., Tsumuraya, T., Kobayashi, N., Nishibori, M., Tanimoto, M., Matsushita, M., 2012. Tumour lineage-homing cell-penetrating peptides as anticancer molecular delivery systems. Nat. Commun. 3, 951. https://doi.org/10.1038/ncomms1952.

Lindgren, M.E., Hällbrink, M.M., Elmquist, A.M., Langel, U., 2004. Passage of cell- 
penetrating peptides across a human epithelial cell layer in vitro. Biochem. J. 377, 69-76. https://doi.org/10.1042/BJ20030760.

Martín, I., Teixidó, M., Giralt, E., 2010. Building cell selectivity into CPP-mediated strategies. Pharmaceuticals 3, 1456-1490. https://doi.org/10.3390/ph3051456.

Meli, M., Morra, G., Colombo, G., 2008. Investigating the mechanism of peptide aggregation: insights from mixed Monte Carlo-molecular dynamics simulations. Biophys. J. 94, 4414-4426. https://doi:10.1529/biophysj.107.121061.

Munyendo, W.L., Lv, H., Benza-Ingoula, H., Baraza, L.D., Zhou, J., 2012. Cell penetrating peptides in the delivery of biopharmaceuticals. Biomolecules 2, 187-202. https://doi. org/10.3390/biom2020187.

Özkay, Y., Yurttaş, L., Dikmen, M., Engür, S., 2016. Synthesis and antiproliferative activity evaluation of new thiazole-benzimidazole derivatives using real-time cell analysis (RTCA DP). Med. Chem. Res. 25, 482-493. https://doi.org/10.1007/s00044016-1507-0.

Parrino, B., Attanzio, A., Spanò, V., Cascioferro, S., Montalbano, A., Barraja, P., Tesoriere, L., Diana, P., Cirrincione, G., Carbone, A., 2017. Synthesis, antitumor activity and CDK1 inhibiton of new thiazole nortopsentin analogues. Eur. J. Med. Chem. 138, 371-383. https://doi.org/10.1016/j.ejmech.2017.06.052.

Pinyol, M., Cobo, F., Bea, S., Jares, P., Nayach, I., Fernandez, P.L., Montserrat, E., Cardesa, A., Campo, E., 1998. p16(INK4a) gene inactivation by deletions, mutations, and hypermethylation is associated with transformed and aggressive variants of nonHodgkin's lymphomas. Blood 91, 2977-2984.

Pujals, S., Giralt, E., 2008. Proline-rich, amphipathic cell-penetrating peptides. Adv. Drug Deliv. Rev. 60, 473-484. https://doi.org/10.1016/j.addr.2007.09.012.

Rothbard, J.B., Garlington, S., Lin, Q., Kirschberg, T., Kreider, E., McGrane, P.L., Wender, P.A., Khavari, P.A., 2000. Conjugation of arginine oligomers to cyclosporin A facilitates topical delivery and inhibition of inflammation. Nat. Med. 6, 1253-1257. https://doi.org/10.1038/81359.

Senkowski, W., Zhang, X., Olofsson, M.H., Isacson, R., Hoglund, U., Gustafsson, M., Nygren, P., Linder, S., Larsson, R., Fryknas, M., 2015. Three-dimensional cell culturebased screening identifies the anthelmintic drug nitazoxanide as a candidate for treatment of colorectal cancer. Mol. Cancer Ther. 14, 1504-1516. https://doi.org/10.
1158/1535-7163.MCT-14-0792.

Shen, L., He, P., 2007. An electrochemical immunosensor based on agarose hydrogel films for rapid determination of ractopamine. Electrochem. Commun. 9, 657-662. https:// doi.org/10.1016/j.elecom.2006.10.049.

Siegel, R.L., Miller, K.D., Jemal, A., 2015. Cancer statistics, 2015. CA. Cancer J. Clin. 65, 5-29. https://doi.org/10.3322/caac.21254.

Sporn, M.B., 1996. The war on cancer. Lancet 347, 1377-1381. https://doi.org/10.1016/ S0140-6736(96)91015-6.

Sun, H., Chow, E.C., Liu, S., Du, Y., Pang, K.S., 2008. The Caco-2 cell monolayer: usefulness and limitations. Expert Opin. Drug Metabol. Toxicol. 4, 395-411. https://doi. org/10.1517/17425255.4.4.395.

Tan, M., Lan, K.H., Yao, J., Lu, C.H., Sun, M., Neal, C.L., Lu, J., Yu, D., 2006. Selective inhibition of ErbB2-overexpressing breast cancer in vivo by a novel TAT-based ErbB2targeting signal transducers and activators of transcription 3-blocking peptide. Cancer Res. 66, 3764-3772. https://doi.org/10.1158/0008-5472.CAN-05-2747.

Vale, N., Correia-Branco, A., Patrício, B., Duarte, D., Martel, F., 2017b. In vitro studies on the inhibition of colon cancer by amino acid derivatives of bromothiazole. Bioorg. Med. Chem. Lett. 27, 3507-3510. https://doi.org/10.1016/j.bmcl.2017.05.073.

Vale, N., Ferreira, A., Alves, C., Araújo, M.J., Mateus, N., Gomes, P., 2017a. Gemcitabine anti-proliferative activity significantly enhanced upon conjugation with cell-penetrating peptides. Bioorg. Med. Chem. Lett. 27, 2898-2901. https://doi.org/10.1016/ j.bmcl.2017.04.086.

Vivès, E., Brodin, P., Lebleu, B., 1997. A truncated HIV-1 Tat protein basic domain rapidly translocates through the plasma membrane and accumulates in the cell nucleus. J. Biol. Chem. 272, 16010-16017. https://doi.org/10.1074/jbc.272.25.16010.

Wang, L., Chen, H., Yu, J., Lin, X., Qi, J., Cui, C., Xie, L., Huang, S., 2016. CPP2-p16MIS treatment - induced colon carcinoma cell death in vitro and prolonged lifespan of tumor-bearing mice. BMC Canc. 16, 1-8. https://doi.org/10.1186/s12885-0162498-4.

Zorko, M., Langel, Ü., 2005. Cell-penetrating peptides: mechanism and kinetics of cargo delivery. Adv. Drug Deliv. Rev. 57, 529-545. https://doi.org/10.1016/j.addr.2004. 10.010 . 